Journal of Education and Vocational Research

Vol. 6, No. 2, pp. 34-41, June 2015 (ISSN 2221-2590)

\title{
Current Practice Performance Measurement Model: A Case Study in Indonesia
}

\author{
Mattoasi ${ }^{1}$, Rose Shamsiah Samsudin ${ }^{2}$ \\ ${ }^{1}$ Gorontalo State University, Gorontalo, Indonesia \\ 2Universiti Utara Malaysia, Kedah, Malaysia \\ mattosuming@gmail.com
}

\begin{abstract}
Understanding performance measurement in the public sector organization is very important in looking into the early performance of local governments. This is because having a good performance measurement model in place serves as part of the accountability to stakeholders (e.g., society as taxpayers). Choosing the right model of performance measurement will have an impact on the performance of the government. In this research, preliminary literature study conducted found that the model of performance measurement, which was used in Indonesia in the old order as well as the new order, was an old model (traditional). The traditional model tends to be input-oriented, causingthe model to be unfit or unsuitable with the current situation. In this concept paper, which also initially analyzing the contents of documents associated with Government Performance Accountability Report (LAKIP) for several years were reviewed and reveals that after the LAKIP model was applied in Indonesia, the local government performance which now focuses on the output level helps overcoming the disadvantages of the previous models in place.
\end{abstract}

Keywords: Performance measurement, Performance measurement model, Traditional model, Accountability, and Local Governments

\section{Introduction}

Indonesia is a republic, which was officially independent on 17 August 1945. To date, Indonesia has gone through three reigns in terms of government administrative, namely the old order, the new order, and the reformation eras. During the eras of old order and the new order, a centralized system was applied (Law No. 05/1974), whereas in the reformation era, local governments (i.e., provinces and districts) have been given greater authority through the implementation of the local autonomy systems (Law No. 22/1999). In the context of governance, the success of a central government or local government can be assessed from the ability of the governments to use the budget efficiently, effectively, and economically to achieve the desired goals (Govindarajan, 1984). In line with that, during the old order, the new order, and also the reformation, the local government performance was assessed based on the government's ability to maximize the use of the budget to improve the quality of public services. Accordingly, every year the central and local governments are required to account for and report on the use of resources, both financial and non-financial resources as a way of executing the accountability process and ensuring that public funds were used according to what was intended for. The report serves asevidence of accountability and transparency to all government stakeholders, especially the public as the taxpayers (Mulyadi, 2000).

In supporting the accountability and transparency of the annual government performance, it is necessary to set an appropriate performance measurement model, to prevent the government officials from mis allocating or mis using the public funds collected through taxes and levies. In line with this, the government has used several performance measurement models to assess the success of the government in providing services to the public. Some of performance measurement models used are1) Model of Cash Systems; and 2) Regional Financial Administration Manual (MAKUDA). With these models, the budgeting systems were developed based the line item budgeting and incremental budgeting. However, as the models were applied, several weaknesses were identified. The main weakness is that the model tends to be short-term-oriented and inputoriented. Hence, it hindered the local government from obtaining and determining long-term performance achievements. Later on, during the reformation era, in which the regional autonomy started to be applied; local governments were required to start implementing a performance measurement model that is not only input-oriented, but also focus on output and outcome oriented. 
Due to the flaws found in the traditional models, reformation era took place with the implementation of the regional autonomy system of government, where the local government has implemented a performance measurement model based on President Instruction Number 7/1999 about using the LAKIP model, which is based on performance-based budgeting. In this context, the LAKIP model can be used to measure the performance of local governments in a more comprehensive manner taking into account both financial and non-financial aspects. The model also gives attention to output and outcomes in a short term period as well as having impacts and benefits orientation in a long term. Based on the background on the changes that took place over the period impacting local governments' performance, this study intends to look into the extent of the effectiveness of performance measurement model (LAKIP) application during the regional autonomy in Indonesia. As such, this paper plans to account for of the application of performance measurement model used in Indonesia more specifically the local governments after decentralization. This introduction part will be followed by some literature review; a methodology section, a discussion, including on advantages and disadvantages of the traditional model with input orientation and advantages of outputs and outcomesoriented measurement model and lastly, some conclusion remarks.

\section{Literature Review}

Performance: Basically, performance is an achievement obtained from a process that begins with planning, and continued by execution, leading to finally producing a valuable output. Armstrong and Baron (1998) argued that performance is the result of work that has a relationship with the organization's goals. Meanwhile, Dubnick (2005) proposed that performance is the result obtained by an organization that has competence, and it must be in line with the quality of the actionsin orderto get quality achievement (Bouckaert and Halligan, 2008). From the explanation and in relation to the public sector, it can be understood that performance is thus defined as the ability to provide a quality service to the community at large. Fenwick (1995) stated that performance is achievements that have the value of efficient, effective and economical. In relation to this, the State Administration Institute (2006) explained that performance is basically the result of a process in achieving goals that could have a positive impact on an organization. However, it should be understood that performance of a public sector organization is normally referred to the quality service to the community, while the performance of the private sector is reflected via high profit earned.

Performance Measurement: Public sector organizations manage their financial resources generated from local revenues such astaxes and levies, which were charged to the community (Law No. 33/2004). Correspondingly, local government performance measurement should be done as a reporting and as a prove that accountability of government to the community regarding the use of available resources has been served. This measurement is done at the end of the fiscal year. The government accountability to the people in the form of organizational performance report is expected to be a guideline for organizations in providing services to stakeholders, especially to the public. The use of government finances obtained from the public must be managed effectively and efficiently. So that, the outputs and outcomes may benefit the community. Hood (1995), Bouckaert and Pollitt (2000), Alexander et al. (2010), and Mitchell (2012) stated that the local government performance can be measured from the effectivity and efficiency of the objectives' achievement, as well as attention to the concept of accountability in the report of performance measurement. In addition, LeRoux and Wright (2010) suggested that there is a need to consider the workload and productivity.The opinions mentioned above indicated that the effectivity and efficiency of the use of local government resources affect the performance of the local governments. Not only in the input level but also in the output and outcome levels. This situation is in line with the explanation from Wallis and Gregory (2009), Packard (2010), and Thomson (2010), who said that any change in the work achievement (from the stage input, output and outcome) of local government also finally affects the community.

Rutgers and van-der-Meer (2010) and Chan and Rosenbloom (2010) in their studies explained that the performance measurement of public sector with orientation of the inputs, outputs, and outcomes, can be improved up to the stage of accountability and transparency of organization to the community. The above description shows that every reporting and accountability outcomes will generate information that can be used by local government in making decisions. Correspondingly, Marr (2009); Aaron (2009); and David et al. (2013) suggested that proper performance measurement in place will produce appropriate information, in 
the hope that such information be clearly stated and usable for decision-making purpose. Meanwhile, Sanger (2013), Bente and Fleming (2014), and Majuta (2014) are ofthe opinion that reporting and accountability of performance is an indispensable information needed by the government in making decision. Based on the above description, it can be concluded that the performance measurement in the public sector is need not only be up to the output level but can be extended or upgraded to the level of impacts and benefits to the community. In line with this, to have a good performance measurement model that will enhanced the accountability and transparency of local government performance is highly required.

Model of Performance Measurement: As part of their accountability process, the local governments need to account for their performance at least annually. Hence, Lane (2000) and Fryer et al. (2009) explained that the local governments are required to establish appropriate model of performance measurement so that the results of performance measurement could be more credible and usable, including being used as information for management decision making (Kennerley and Neely, 2002). This suggests that the expected performance measurement model must be in line with the needs of the organization. Consequently, the indispensable information expected to be supplied for the society in the preparation of government accountability reports include programmes and the use the budget, and whether they are in accordance with the organization's vision (Cavalluzzo and Ittner, 2004; Chenhall, 2005). The change in performance measurement models in the public sector from the input orientation into the output and outcome orientation is the basic concept of performance measurement model based on the New Public Management (NPM). The NPM generates performance reports that consider the aspect of accountability and transparency. This is as expressed by (Herawaty and Hoque, 2007; Hoque and Adams, 2011). They explained that the current performance measurement model is more transparent to meet the needs of internal and external to the organization. Meanwhile, Morgan (2013) explained that the goal of reporting on the performance of public sector organizations with the concept of NPM is to fulfill the information needs of the organizational stakeholders. It should contain the extent to which the organization has achieved the expected performance.

The description above is in line with the study of Andrews (2011) and Carol et al. (2014); that says that the performance measurement is intended to get the effective, and efficient performance, and have impact to society because at the end of the day, organization needs to report on the achievements. However, in addition to aspects of effectiveness, efficiency and impact, it is important to pay attention to the quality aspects of a program (Queeneville et al., 2010; Zafra-Gomes et al., 2012). In summary, based on description of the performance measurement models above, it can be understood that any model of performance measurement is expected to be in line with the needs of the organization and also serves the information need of stakeholders. Local government performance measurement model developed must take into considerations the concept of NPM that pays attention to the financial aspects and non-financial aspects and also considers the aspect of output, outcome, impacts and also benefits.

\section{Methodology}

This study reviewed the work of others on performance measurement models as well as in Indonesia. It was intended to obtain information on the effectiveness of the application of performance measurement model used by local government in Indonesia after the regional autonomy was implemented. This is in line with the view of Weber (1985) that content analysis is valuable in understanding the meaning behind the text. Similarly, Miles and Huberman (1994) not much different from Patton (2002) suggested that the data obtained from document needs to be reviewed, coded, and analyzed so that, the key words for a thought and concept can be generated,enabling analysis and offering meanings to the matters understudy.

\section{Discussion}

Traditional Model: Basically, the Model of Cash System Performance Measurement and the Model of Regional Financial Administration Manual (MAKUDA) were used during the old order and new order. These two models have a characteristic that use the determination of the government budget by following line items budgeting approach. In doing so, the budget was established by following each budget items in the previous year's record. Budgets were annually rementalism concept, by adding or reducing a certain amount of dollars for some items by using the financial data in the previous year.With regards to this, the application of 
performance measurement models in Indonesia during the old order had been in line with several previous studies. For example, Wildavsky (1964) stated that the budgeting model created based on the line item budgeting was a "budget history", and is not appropriate to use in assessing the success of a program, because it is an input-oriented and tends to be short-term oriented. In line with the above study, Shah and Shen (2007) revealed that the main characteristic of the line item budgeting system is an upper limit. The upper limit is set during the budget allocation process. Expenditures were not allowed to exceed the upper limit. Furthermore, Rubin (2007) argued that since the line item budgeting model has limited resources (input controlled), it was expected to effectively control the level of expenditures. Also, it was expected that good allocation of resources would help to improve the budget efficiency. Based on the above opinions on the performance measurement models, it is concluded that these models cannot be used optimally for sustainable management of government budgets, because the models accommodate for only short-term input and expenditures and tends to be financial oriented. In addition,the models seem to have minimal considerations on performance from the human resources aspect.

Advantages of Traditional Performance Measurement Model: The applications of performance measurement model used during the Old Order and the New Order, either in the form of Cash Systems or MAKUDA as described in the Traditional Budgetary System have several advantages in its implementation in Indonesia. The study by Halim (2002) found that the implementation of performance measurement model based on the traditional budget has several advantages, namely; 1 ) the model is easy to arrange, 2) it does not require a lot of human resources, and ) the conflict between divisions is the very low. In line with the above view, the same perspective was offered by Mulyadi (2002) who stated that some of the advantages are as follows; 1) a very simple model, 2) easy to understand, 3) a tight budget control, 4) more flexible in the supervision of the use of resources 5) can be used as a basis for determining the budget for the next stage. The same opinion was also expressed by Jones and Pendlebury (1996) and Ulum (2004). In addition to what was highlighted before, they stated that the advantages of traditional measurement models included 1) easy to be implemented 2) easy to control because it is centralized, and 3) ongoing government programs can be performed. In summary, the traditional performance measurement model, which was prepared under the line item budgeting and incremental budget that was applied in Indonesia has advantages in terms of the ease of applying and understanding. This is in line with the study by Rubin (2007) and Shah and Shen (2007), who quoted this model as not requiring excessive resources in carrying out the activities with strict or minimal supervision.

Disadvantages of Traditional Performance Measurement Model: The application of Traditional Performance Measurement models (i.e., cash system and MAKUDA models) carries many advantages. Nevertheless, studies also pointed out a number of weaknesses in its implementation. Mardiasmo (2002) found some disadvantages of the traditional performance measurement models as follows; 1 ) the effectiveness of spending is less scalable because of the use of incremental system, 2) the nature of the budget is disjointed 3) having input orientation, so that there is a tendency to finish the budget, 4) the competition between the units in organization in performance assessment, 5) there is a separation between the regular budget and development budget, 6) it is an annual budget, 7) it is centralized, 8) approval of the budget is often delayed due to waiting for approval from the central government, and 9) flow of information is inadequate. In line with Mardiasmo (2002), the results of the analysis of the Apostle (2003) also showed some weaknesses in the traditional model. The weaknesses are the model namely, 1) accountability of performance achievement is not transparent because its orientation is only on expenditures' control, 2) the base of budget is not clear, and 3) it is less flexible. Based on the views above, it is concluded that the Traditional Performance Measurement models (Cash system or MAKUDA) need some improvements. This input-oriented performance measures can be developed into a better model with the orientation being focus on theoutputs and outcomes instead.

Performance Measurement Model with Output and Outcome Orientation: A number of literatures have demonstrated that the performance measurement models used by the government during theOld Order and the New Order carried some weaknesses. This led to conclusion that the models need to be replaced, because the models are no longer compatible with current scenario, practices as well as the expectations of society. Accordingly, after the regional autonomy policy was established through the Law No. 32/1999, the centralized government was applying a decentralized system whereby the local government authority, either 
at the provincial level or district level, was administered by the local governments. The government is supported by the financial sourced from local revenues and the allocation of funds from the central government (Law No. 25/1999). Based on the law, local governments are given the authority to set their own area with financial support comes from local revenues in the form of taxes, retribution, and the allocation of funds from the central government. However, the submission of such authority does not intend to give full freedom to the local government because they still have to obey the rules of the central government, through the Performance Accountability Report (LAKIP) based on the Presidential Decree No. 7 of 1999, to the central government every year (LAN, 1999). The basic concept of LAKIP model is to amend the traditional Performance Measurement Model, which used the principle that the balanced of budget (between revenues and expenses) must be zero at the end of the year, into a performance-based budgeting. The LAKIP model begins with the elements of strategic planning and organizational objectives. In addition, the performance measurement elements include the elements of the organization's objectives, performance indicators to be achieved, target, realization, and achievement.

The above description shows that the LAKIP model of local government performance, designed based on a performance-based budgeting, has a clearer planning and performance indicators compared to the Traditional Performance Measurement model (stewart, 1994; Young, 2003). Buschor (2013) in his study cited that the use of organizational resources is expected to reach the stage of output, outcome, impact as well as benefits. By accommodating all these elements, the impact from the use of public funds to execute activities can be felt by the community at large. The above description shows that the LAKIP performance measurement model used by the government at the regional autonomygives more emphasis on quality than quantity gains from the program implemented because focus were given beyond financial performance but extend to the outcome and impact of the money spent. This is consistent with Carlin (2004), Diamond (2005), Robinson and Brumby (2005), shah and Shen (2007), Robinson and Last (2009), and Hou (2010) who in their studies stated that the performance measurement models like LAKIP is a form of local government accountability in managing financial sourced from the public. Meanwhile, Rubin (2007) in support of the model said that the local government finance should be used with clear performance targets in order to provide benefits to the community.

In summary, the views on LAKIP is that the orientation of organizational performance measurement is expected to reach the stage of outcome in the short-term, and it is also expected to reach the stage of the impact and benefits in the long-term in order to ensure that the performance of local governments can be more effective and efficient. This is in line with the opinion of Robinson and the Last (2009), and Taylor et al. (2011) who stated that the use of the budget must always be associated with the results to be achieved, and can be measured from the aspects of effectiveness and efficiency. Similarly, studies of Sandalgaard et al. (2011) who postulated that the budgeting-based model of performance measurement needs to be adjusted periodically following the development of public purposes, so that local government spending becomes more effective. Afterall, the local governments are the closest to the public at large in terms of providing public services and amenities by government administration. From this study, it was gathered that budgeting-based performance measurement is more effective than the traditional model which focused on input orientation. In line with that, some researchers found that LAKIP model is more suitable to be applied in Indonesia. In the government regulation number 58 of 2005, it was described that performance of local governments should be reported annually and need to be publicly presented to the stakeholders, especially to the public.

In support of that, Simbolon (2003) for example stated that the LAKIP performance measurement model has an advantage because 1) the model LAKIP has a principle of accountability, 2) it has the priority principle, and 3 ) it has the benefit principle. Similarly Darise (2008) also gave the opinion that the application of the LAKIP performance measurement model in Indonesia carries several advantages which include 1) the model is based on performance-based budgeting, 2) it considers the relationship between program and output, and 3) it emphasizes the quality and not only the quantity of achievements. The above opinions shows that the LAKIP performance measurement model has a clear planning in determining the performance to be achieved, so as it can be reported back as a form of government accountability to the public. This is in line with the view of Mardiasmo (2002), who said that after the LAKIP model has been effectively applied, it brings a number benefits, such as 1) the model is arranged based on the activity, 2) it prioritize outputs than inputs 3 ) and it is based on value for money, and 4) the model is flexible. From the above discussion, it seems that local 
government performance measurement in Indonesia in regional autonomy era has been implemented based on the concept of NPM because as prescribed by NPM, the model currently in place in Indonesia is characterized by measurement orientation focusing on outputs and outcomes. Hence, it can be understood that the performance of local governments in Indonesia during the reform era has been reported and presented based on the principles of accountability and transparency because input, output, outcome and impacts are clearly defined and later on aligned in order to know whether planning and performance expected has been achieved.

\section{Conclusion}

Based on past studies conducted and a few available local documents reviewed on the change in the performance measurement models and gradually the implementation of LAKIP, it can be said that the previous performance measurement model that is traditionally applied to the new order has various weaknesses, giving way to the introduction of LAKIP, which have an output and outcome. The new model (LAKIP) also promote the elements of strategic long-term planning, a concerns for outcome and impacts, and also accountability and transparency. Since this paper only covers a preliminary study on the development of the previous models to what is currently in practice in Indonesia (LAKIP) through literature reviewed, further studies need to look not only into its establishment but also into the implementation of the new model (LAKIP) as well as whether it is successfully applied to the local government.

\section{References}

Aaron, W. (2009). Understanding the Difference between Performance Reporting and Performance Management. State and Local Government Review, 1, 174.

Halim, A. (2002). Seri Akuntansi Sektor Publik-Akuntansi Keuangan Daerah, Jakarta: Salemba Empat.

Alexander, J., Brudney, J. L. \& Yang, K. (2010). Introduction to the Symposium: Accountability and performance measurement: The evolving role of nonprofits in the hollow state. Non-profit and Voluntary Sector Quarterly, 39(4), 565-570.

Andrews, R. (2011). New Public Management And The Search For Efficiency. In T. Christensen \& P. Lægreid (Eds.), The Ashgate research companion to new public management, pages 281-294.

Armstrong, M. \& Baron, A. (1998). Performance Management - The New Realities. The American Political Science Review, 60, 29-47.

Audrey, T., Tamara, K. \& Suzanne, K. (2011). Strategic Budgeting In Public Schools: An experimental comparison of budget formats. Advances in Management Accounting (Advances in Management Accounting, 19, 133 - 160

Bente, B. \& Flemming, L. (2014). The Politics Of Performance Measurement: Evaluation use as mediator for politics. Sage jurnal, 20, 400-411.

Bouckaert, G. \& Halligan, J. (2008). Managing Performance: International Comparisons. London, Routledge CA: Sage.

Carlin, T. M. (2004). Output Based Budgeting and the Management of Performance. Macquarie Graduate School of Management. Sidney.

Carol, A. A., Stephen, M. \& Zahirul, H. (2014). Measurement of Sustainability Performance in the Public Sector. Sustainability Accounting. Management and Policy Journal, 5(1), 46 - 67.

Cavalluzzo, K. S. \& Ittner, C. D. (2004). Implementing Performance Measurement Innovations: Evidence from Government. Accounting, Organizations and Society, 29, 243-67.

Chan, H. S. \& Rosenbloom, D. H. (2010). Four Challenges to Accountability in Contemporary Public Administration. Lessons from the United States and China. Administration \& Society, 42, 11S - 33S.

Chenhall, R. H. (2005). Adoption and Benefits of Management Accounting Practices: An Australian Study. Management Accounting Research, 9, 1-19.

Pollitt, C. \& Bouckaert, G. (2000). Public Management Reform: A Comparative Analysis Oxford University Press, 2000,328 pages.

David, N. A., Ellen, G. L. \& Jordan, A. J. (2013). Performance Management Purpose, Executive Engagement, and Reported Benefits among Leading Local Governments. State and Local Government Review, 45, 172179. 
Diamond, J. (2005). Establishing a Performance Management Framework for Government. International Monetary Fund. Working Paper 05/50.

Dubnick, M. (2005). Accountability and The Promise of Performance: In search of mechanisms. Public performance and Management Review, 28, 376-417.

Buschor, E. (2013). Performance Management in the Public Sector: Past, current and future trends. Original Research Article Tékhne, 11(1), 4-9.

Fenwick, J. (1995). Managing Local Government. London. Chapman and Hall.

Fryer, K., Antony, J. \& Ogden, S. (2009). Performance Management in the Public Sector. International Journal of Public sector Management, 22(6), 478-498.

Govindarajan, V. (1984). Appropriateness of Accounting Data in Performance Evaluation: An Empirical Animation of Environmental Uncertainty an Intervening Variable. Accounting Organ. and Society, 1, 125-135.

Hood, C. (1995). The New Public Management in the 1980s: Variations on a theme. Accounting Organizations and Society, 20, 93-109.

Hoque, Z. \& Adams, C. A. (2011). The Rise And Use Of Balanced Scorecard Measures In Australian. Financial Accountability \& Management, 27(3), 308-334.

Hou, Y. (2010). The Performance of Performance-Based Budgeting American Society for Public Administration (ASPA) San Jose, CA, 9-13.

Ulum I. (2004). Akuntansi Sektor Publik, UMM PRESS, Yogyakarta.

Jones, R. \& Pendlebury, M. (1996). Public Sector Accounting, Business and economic. London.

Kennerley, M. \& Neely, A. (2002). A Framework Of The Factors Affecting The Evolution Of Performance Measurement Systems. International Journal of Operations \& Production Management, 22(11), 225226.

Lane, J. E. (2000). New Public Management, Routledge, London.

LeRoux, K. \& Wright, N. S. (2010). Does Performance Measurement Improve Strategic Decision Making? Findings from a national survey of nonprofit social service agencies. Non-profit and Voluntary Sector Quarterly, 39(4), 571-587.

Majuta, J. M. (2014). Financial Performance of Local Government in Limpopo Province, 2010-2012. African Studies Quarterly, 15(1), 81.

Mardiasmo. (2002). Akuntansi Sektor Publik. ANDI Yogyakarta, Yogyakarta.

Marr, B. (2009). Managing and Delivering performance: How Government, public sectors, and not for profit organization can measure and manage what really matters. Oxford, UK: Butterworth-Heineman.

Herawaty, M. \& Hoque Z. (2007). Disclosure In The Annual Reports Of Australian Government Departments: A research note. Journal of Accounting \& Organizational Change, 3(2), 147-168

Miles, M. B. \& Huberman, A. M. (1994). Qualitative Data Analysis: An expanded sourcebook. Thousand Oaks

Mitchell, G. E. (2012). The Construct Of Organizational Effectiveness: Perspectives from leaders of international nonprofits in the United States. Non profit and Voluntary Sector Quarterly. Advance online publication. doi: $10.1177 / 0899764011434589$.

Morgan, G. G. (2013). Purposes, Activities and Beneficiaries: assessing the use of accounting narratives as indicators of third sector performance. Qualitative Research in Accounting \& Management, 10(3/4), 295-315.

Mulyadi. (2002). SistemTerpadu Pengelolaan Kinerja Personal Berbasis Balance Scorecard, Penerbit UPP STIM YKPN.

Mulyadi. (2000). Auditing. Edisi ke-6. Jakarta: Salemba empat.

Sandalgaard, N., Bukh, P. N. \& Stig, P. C. (2011). The interaction between motivational disposition and participative budgeting: Evidence from a bank. Journal of Human Resource Costing \& Accounting, 15(1), 7 - 23. Emerald Group Publishing Limited.

Darise, N. (2008). AkuntansiKeuangan Daerah AkuntansiSektorPublik). Indeks, Jakarta.

Packard, T. (2010). Staff Perceptions of Variables Affecting Performance in Human Service Organizations. Nonprofit and Voluntary Sector Quarterly, 39(6), 971-990.

Patton, M. (2002). Qualitative Research and Evaluation Methods. USA. Sage Publication Inc.

Apostle, P. S. (2003). Replaced Traditional Budgeting. California Management Review, 45(4).

Queeneville, M. V., Laurin, C. \& Thibodeu, N. (2010). The Long Run Performance Of Decentralized Agencies In Quebec: A multidimensional assessment. In P. Lægreid\& K. Verhoest (Eds.), Governance of public sector organizations. Proliferation, autonomy and performance, pp. 157-176 
Robinson, M. \& Last, D. (2009). A Basic Model of Performance-Based Budgeting. Technical Notes and Manuals. International Monetary Fund. Washington.

Robinson, M. \& Brumby, J. (2005). Does Performance-Based Budgeting Work?: An Analytical Review of the Empirical Literature. International Monetary Fund. Working Paper 05/pg.210

Rubin, I. (2007). Budget Formats: Choices and Implications. Public Sector and local Government. Washington. The World Bank.

Rutgers, M. R. \& van der Meer, H. (2010). The Origins and Restriction of Efficiency in Public Administration: Regaining Efficiency as the Core Value of Public Administration. Administration \& Society journal, $\mathrm{XX}(\mathrm{X}), 1-25$

Sanger, M. B. (2013). Does Measuring Performance Lead To Better Performance? Journal of Policy Analysis and Management, 32, 185-203.

Shah, A. \& Chunli, S. (2007). Citizen-Centric Performance Budgeting at the Local Level. Public Sector and Governance and Accountability Series: Local Budgeting. World Bank.

Simbolon, K. (2003). Laporan Akuntabilitas Kinerja Instansi Pemerintah. Webmaster - Dispenad. Jakarta.

Stewart, J. \& Walsh. (1994). Performance Measurement: When performance can never be finally defined. Public Money \&Management, 3, 45-49.

Thomson, D. E. (2010). Exploring The Role Of Funders' Performance Reporting Mandates In Nonprofit Performance Measurement. Nonprofit and Voluntary Sector Quarterly, 39(4), 611-629.

Wallis, J. \& Gregory, R. (2009). Leadership, Accountability and Public Value: Resolving a Problem in New Governance. Int. Journal of Public Administration, 32(3-4), 250-273.

Weber, R. P. (1985). Basic Content Analysis. USA : Sage Publication, Inc.

Wildavsky, A. (1964). The Politics of the Budgetary Process. Boston: Little.

Young, R. D. (2003). Performance-Based Budget Systems. Public Policy. International Journal of Public Sector Management, 22, 278-298.

Zafra-Gómez, J. L. P., Plata Díaz, D. A. M. \& López-Hernández, A. M. (2012). Reducing Costs in Times of Crisis: Delivery Forms in Small and Medium Sized Local Governments' Waste Management Services. Public Administration.doi: 10.1111/J.1467-9299.2011.02012.

\section{Local Government Law}

Law ofthe Republic of Indonesiano.22 of 1999on Local Government.

Law ofthe Republic of Indonesia no. 25 of 1999 on Financial Balance Between Central and Local Government. Presidential Decree No. 7of 1999 for Accountability Reports on Government Performance

Institute of Public Administration Indonesia in 1999

Law No.5of 1974 on the foundations of local government 